\title{
Influence of phenolic substances on rooting of softwood cuttings of Populus alba L. and P. canescens Sm.
}

\section{T. BOJARCZUK and L. S. JANKIEWICZ}

Research Institute of Dendrology, Kórnik by Poznań, Research Institute of Pomology, Skierniewice, Poland

(Received: March 22, 1974)

\section{Abstract}

\begin{abstract}
Pyrogallol and salicylic acid used alone or in combination with auxin increased markedly the number of rooted cuttings, the number of roots per cutting and the total length of roots per cutting. The effect of phenolic substances was most visible when treatment was done in late summer, i.e. when natural ability to form roots was very low.
\end{abstract}

\section{INTRODUCTION}

The root-promoting property of phenolic substances was discovered several years ago (Hess 1962; Tom aszew ski 1964), but was as yet little investigated (B a s u 1969; Lee and Tuckey 1971; $\mathrm{Hac}$ kett 1970; J a n kiewicz et al. 1973). It seemed therefore interesting to examine if these substances may improve rooting of cuttings of poplars (section Leuce). Poplars of this section are important in forestry of many countries but their propagation is difficult. Especially the propagation with softwood cuttings gives little success with several clones. With other clones which may be easier propagated with cuttings there is a problem of hastening the rooting to obtain more rotations of cuttings per frame in one season.

\section{MATERIALS AND METHODS}

Cuttings were made of current year shoots taken from one-year-old mother trees of Populus canescens 'Rogalinensis' and of P. alba 'Tryńcza 3' or 'Gniewczyna 2'. One or two cuttings were made of one shoot. The apical part was always rejected since it was found in the preliminary experiment to be very susceptible to diseases. The cuttings contained 3 
nodes. The largest leaves were cut by $1 / 3$, the lowest leaf was removed. The cutings were treated with diluted solutions of phenolic substances for 24 hours and then their lower ends were dipped in talc powder containing $0.2 \%$ or $0.4 \%$ naphtaleneacetic acid (NAA) with or without fungicide. In one experiment the quick-dip method was also used (see Table 5). The cuttings were planted in a greenhouse in $5 \mathrm{~cm}$ layer of washed sand placed on a mixture of sterilized compost soil. The benches with cuttings were cover with windows to avoid too much evaporation. Watering was done 2-3 times a day by hand. Once a week the cuttings were sprayed with $0.3 \%$ Captan.

The results were estimated by counting the number of rooted cuttings per plot with 16 cuttings (in one case 8 ), and also by counting the number of roots per cutting and by measuring the total root length per cutting. The experiment was set up in 3-4 randomized blocks. The results were worked up statistically with the method of analysis of variance using Duncan's multiple range test for significance at $\mathrm{P}=0.05$.

\section{RESULTS}

Populus alba 'Tryńcza 3' cuttings rooted generally better than $P$. canescens 'Rogalinensis' (Table 1) and P. a. 'Gniewczyna 2' (Table 2). The control cuttings of all 3 clones rooted in low number or not at all.

Phenolic substances: pyrogallol and salicylic acid applied alone increased sometimes the number of rooted cuttings of $P$. c. 'Rogalinensis' and of P. a. 'Tryńcza 3' (Table 1), but not of P. a. 'Gniewczyna 2' (Table 2 ). The effect of these substances on the number of roots per cutting and on the root length was none or weak (although in some cases significant).

NAA alone, in talc stimulated rooting in all 3 clones. The joint treatment with phenolic substance (diluted solutions method) and with auxin (in talc) increased the number of rooted cuttings of $P$. $a$. 'Tryńcza 3 ' in 1972 and of $P$. $a$. 'Gniewczyna 2' over the number obtained with NAA alone. This difference was insignificant for $P$. $a$. 'Tryńcza 3 ' in one of the experiments (Table 3). The joint treatment with phenolic substance and with auxin showed, however, always marked synergistic effect on the number of roots per cutting and on the total root length in the cuttings of all 3 clones. The optimal concentration of a phenolic substance in a joint treatment with auxin was in most cases $0.5-5$ or even $20 \mathrm{mg} / \mathrm{l}$ (Tables 1-4).

The fungicide Captan added to the talc preparate with NAA, in a combined treatment with salicylic acid increased the number of rooted cuttings of $P$. a. 'Tryńcza 3' but diminished the root length (Table 1). With other clones its effect was insignificant (Tables 1, 2 and 4).

Salicylic acid, a monophenol promoted rooting of P. a. 'Tryńcza 3' 
Table 1

The influence of salicylic acid on rooting of $P$. alba 'Tryńcza 3' cuttings (1) and of pyrogallol on rooting of $P$. canescens 'Rogalinensis' cuttings (2)

Planted on August 5, results checked on August 26, 1972

\begin{tabular}{|c|c|c|c|c|c|c|}
\hline \multirow{2}{*}{$\begin{array}{c}\text { Treatment } \\
\text { (Concentrations } \\
\text { of phenolic } \\
\text { substances in ppm) }\end{array}$} & \multicolumn{2}{|c|}{$\begin{array}{l}\text { Average number of } \\
\text { rooted cuttings per } \\
\text { plot of } 16 \text { cuttings }\end{array}$} & \multicolumn{2}{|c|}{$\begin{array}{l}\text { Average number } \\
\text { of roots per } \\
\text { cutting }\end{array}$} & \multicolumn{2}{|c|}{$\begin{array}{l}\text { Average total } \\
\text { length of roots } \\
\text { per cutting }\end{array}$} \\
\hline & 1 & 2 & 1 & 2 & 1 & 2 \\
\hline $\begin{array}{l}\text { control } \\
\text { phenolic } \\
\text { substance }\end{array}$ & $3.0 \mathrm{a}$ & $0.0 \mathrm{a}$ & $1.5 \mathrm{a}$ & $0.0 \mathrm{a}$ & $9.3 \mathrm{a}$ & $0.0 \mathrm{a}$ \\
\hline 0.5 & $10.0 \mathrm{c}$ & $2.3 \mathrm{~b}$ & $7.8 \mathrm{ab}$ & $2.2 \mathrm{~b}$ & $33.6 \mathrm{bcd}$ & $4.1 \mathrm{ab}$ \\
\hline 1.0 & 11.7 cdef & - & $9.0 \mathrm{ab}$ & - & $36.3 \mathrm{~cd}$ & - \\
\hline 2.0 & $12.3 \mathrm{defg}$ & $2.0 \mathrm{~b}$ & $8.3 \mathrm{ab}$ & $1.3 \mathrm{~b}$ & $33.6 \mathrm{bcd}$ & $2.9 \mathrm{ab}$ \\
\hline 5.0 & $13.0 \mathrm{efg}$ & $2.0 \mathrm{~b}$ & $7.7 \mathrm{ab}$ & $1.3 \mathrm{~b}$ & $29.9 \mathrm{bcd}$ & $1.9 \mathrm{ab}$ \\
\hline 10.0 & 12.7 defg & - & $8.3 \mathrm{ab}$ & - & $29.1 \mathrm{bcd}$ & - \\
\hline 20.0 & $10.0 \mathrm{c}$ & $2.7 \mathrm{~b}$ & $6.3 \mathrm{a}$ & $2.2 \mathrm{~b}$ & $22.0 \mathrm{~b}$ & $3.8 \mathrm{ab}$ \\
\hline 50.0 & $11.0 \mathrm{~cd}$ & $3.3 \mathrm{~b}$ & $7.6 \mathrm{ab}$ & $2.3 \mathrm{~b}$ & $23.5 \mathrm{~b}$ & $5.7 \mathrm{~b}$ \\
\hline $\begin{array}{l}\text { NAA } 0.2 \%(=\mathrm{n}) \\
\text { phenolic } \\
\text { substance }\end{array}$ & $5.0 \mathrm{~b}$ & $7.0 \mathrm{c}$ & $11.8 \mathrm{c}$ & $4.5 \mathrm{c}$ & $39.7 \mathrm{~d}$ & $17.7 \mathrm{c}$ \\
\hline $0.5+n$ & $11.0 \mathrm{~cd}$ & $10.7 \mathrm{~d}$ & $24.1 \mathrm{e}$ & $10.6 \mathrm{e}$ & $88.1 \mathrm{~g}$ & $42.4 \mathrm{~d}$ \\
\hline $1.0+\mathrm{n}$ & $10.7 \mathrm{~cd}$ & - & $23.9 \mathrm{e}$ & - & $85.1 \mathrm{~g}$ & - \\
\hline $2.0+n$ & $13.3 \mathrm{fg}$ & $9.2 \mathrm{~cd}$ & $23.5 \mathrm{e}$ & $10.3 \mathrm{e}$ & $83.8 \mathrm{~g}$ & $42.6 \mathrm{~d}$ \\
\hline $5.0+\mathrm{n}$ & 11.4 cde & $8.3 \mathrm{~cd}$ & $23.9 \mathrm{e}$ & $10.7 \mathrm{e}$ & $86.3 \mathrm{~g}$ & $41.6 \mathrm{~d}$ \\
\hline $10.0+n$ & 11.3 cde & - & $18.4 \mathrm{~d}$ & - & 59.7 ef & - \\
\hline $20.0+\mathrm{n}$ & $10.7 \mathrm{~cd}$ & $8.7 \mathrm{~cd}$ & $19.1 \mathrm{~d}$ & $9.3 \mathrm{e}$ & 61.4 ef & $39.5 \mathrm{~d}$ \\
\hline $50.0+n$ & $12.3 \mathrm{defg}$ & $8.0 \mathrm{c}$ & $18.0 \mathrm{~d}$ & $7.2 \mathrm{~d}$ & 60.1 ef & $21.7 \mathrm{c}$ \\
\hline $5.0+n+$ captan & $13.7 \mathrm{~g}$ & $9.0 \mathrm{~cd}$ & $21.3 \mathrm{e}$ & $10.0 \mathrm{e}$ & 64.0 ef & $40.5 \mathrm{~d}$ \\
\hline
\end{tabular}

The numbers marked with the same letter do not differ significantly at $P=0.05$.

cuttings similarly or even better than pyrogallol - a polyphenol (Table 1 and 3). In one separate experiment, however, salicylic acid showed only weak and in most cases insignificant effect on the number of roots per cutting in P. c. 'Rogalinensis' (Table 4), its effect with NAA on total length of roots per cutting was, however, marked and synergistic even in this case.

Since the method of application of growth regulators in concentrated solutions (quick-dip method) is more convenient in practice than diluted solutions method, we applied salicylic acid with this method for the cuttings of P. a. 'Tryńcza 3' (Table 5). It was found that all concentrations, which were used, of this compound alone, increased markedly the number of rooted cuttings and the number of roots per cutting, but not the total lenght of roots per cutting. The auxin used separately showed also marked effect on adventitious roots production. Joint treatment with 
Table 3

The influence of pyrogallol on rooting of $P$. alba 'Gniewczyna 2' cuttings (Planted on August 4, results checked on August 26) (Other details as in Table 1)

\begin{tabular}{|c|c|c|c|c|}
\hline \multicolumn{2}{|c|}{ Treatment } & $\begin{array}{c}\text { Average number } \\
\text { of rooted cuttings } \\
\text { per plot of } 16 \\
\text { cuttings }\end{array}$ & $\begin{array}{l}\text { Average } \\
\text { number no of } \\
\text { roots per } \\
\text { cutting }\end{array}$ & $\begin{array}{l}\text { Average total } \\
\text { length or roots } \\
\text { per cutting }\end{array}$ \\
\hline \multirow{13}{*}{$\begin{array}{l}\text { Control } \\
\text { Pyrogallol }\end{array}$} & & $2.0 \mathrm{a}$ & $2.1 \mathrm{a}$ & $4.1 \mathrm{a}$ \\
\hline & $0.5 \mathrm{ppm}$ & $2.0 \mathrm{a}$ & $3.5 \mathrm{a}$ & $3.9 \mathrm{a}$ \\
\hline & 2.0 & $2.0 \mathrm{a}$ & $2.0 \mathrm{a}$ & $3.5 \mathrm{a}$ \\
\hline & 5.0 & $3.3 \mathrm{a}$ & $1.6 \mathrm{a}$ & $4.2 \mathrm{a}$ \\
\hline & 20.0 & $3.0 \mathrm{a}$ & $3.0 \mathrm{a}$ & $4.0 \mathrm{a}$ \\
\hline & 50.0 & $3.0 \mathrm{a}$ & $2.0 \mathrm{a}$ & $4.3 \mathrm{a}$ \\
\hline & $(=\mathrm{n})$ & $9.3 \mathrm{~b}$ & $10.6 \mathrm{~b}$ & $16.3 \mathrm{~b}$ \\
\hline & $0.5+\mathrm{n}$ & $13.3 \mathrm{c}$ & $13.3 \mathrm{~cd}$ & $51.3 \mathrm{e}$ \\
\hline & $2.0+\mathrm{n}$ & $13.0 \mathrm{c}$ & $13.7 \mathrm{~d}$ & $55.3 \mathrm{f}$ \\
\hline & $5.0+\mathrm{n}$ & $13.7 \mathrm{c}$ & $13.4 \mathrm{~cd}$ & $44.9 \mathrm{~d}$ \\
\hline & $20.0+n$ & $10.3 \mathrm{~b}$ & $12.1 \mathrm{bcd}$ & $40.6 \mathrm{c}$ \\
\hline & $50.0+n$ & $9.7 \mathrm{~b}$ & $11.7 \mathrm{bc}$ & $40.7 \mathrm{c}$ \\
\hline & $5.0+n+$ captan & $14.0 \mathrm{c}$ & $12.2 \mathrm{bcd}$ & $47.2 \mathrm{~d}$ \\
\hline
\end{tabular}

Ta ble 3

The influence of salicylic acid, pyrogallol and NAA

on the rooting of $P$. alba 'Tryńcza 3' cuttings

(Planted on August 4, results checked on August 25) (Other details as in Table 1)

\begin{tabular}{|l|c|c|c|}
\hline \multicolumn{1}{|c|}{ Treatment } & $\begin{array}{c}\text { Average number } \\
\text { of rooted } \\
\text { cuttings per plot } \\
\text { of 8 cuttings }\end{array}$ & $\begin{array}{c}\text { Average number } \\
\text { of roots per } \\
\text { cutting }\end{array}$ & $\begin{array}{c}\text { Average total } \\
\text { length of roots } \\
\text { per cutting }\end{array}$ \\
\hline Control & 6.7 & $4.1 \mathrm{a}$ & $10.4 \mathrm{a}$ \\
Salicylic acid $1.0 \mathrm{ppm}$ & 6.7 & $5.2 \mathrm{a}$ & $17.0 \mathrm{a}$ \\
Salicylic acid 5.0 ppm & 7.7 & $5.0 \mathrm{a}$ & $18.5 \mathrm{a}$ \\
Pyrogallol 1.0 ppm & 7.7 & $5.0 \mathrm{a}$ & $18.5 \mathrm{a}$ \\
Pyrogallol 5.0 ppm & 7.7 & $7.1 \mathrm{a}$ & $50.8 \mathrm{~b}$ \\
NAA 0.2\% (=n) & 7.7 & $13.5 \mathrm{bc}$ & $68.5 \mathrm{c}$ \\
Salicylic acid 1.0+n & 7.7 & $21.2 \mathrm{f}$ & $65.0 \mathrm{c}$ \\
Salicylic acid 5.0 $\mathrm{n}$ & 8.0 & $18.0 \mathrm{de}$ & $69.4 \mathrm{c}$ \\
Pyrogallol 1.0+n & 7.3 & $16.0 \mathrm{~cd}$ & $63.4 \mathrm{c}$ \\
Pyrogallol 5.0 $\mathrm{n}$ & 7.7 & & \\
\hline
\end{tabular}

both substances increased only slightly the number of rooted cuttings over the number obtained with salicylic acid alone (significant difference only for some concentrations), but showed marked additive effect on the number of roots per cutting and on the total length of roots per cutting. 
Thus salicylic acid can be used with a convenient quick-dip method instead of diluted solutions method. The concentrations $1000 \mathrm{mg} / \mathrm{l}-5000$ $\mathrm{mg} / \mathrm{l}$ in a joint treatment with auxin seem to be optimal.

Table 4

The influence of salicylic acid on rooting of $P$. canescens 'Rogalinensis' cuttings (Planted on August 4, results checked on August 26)

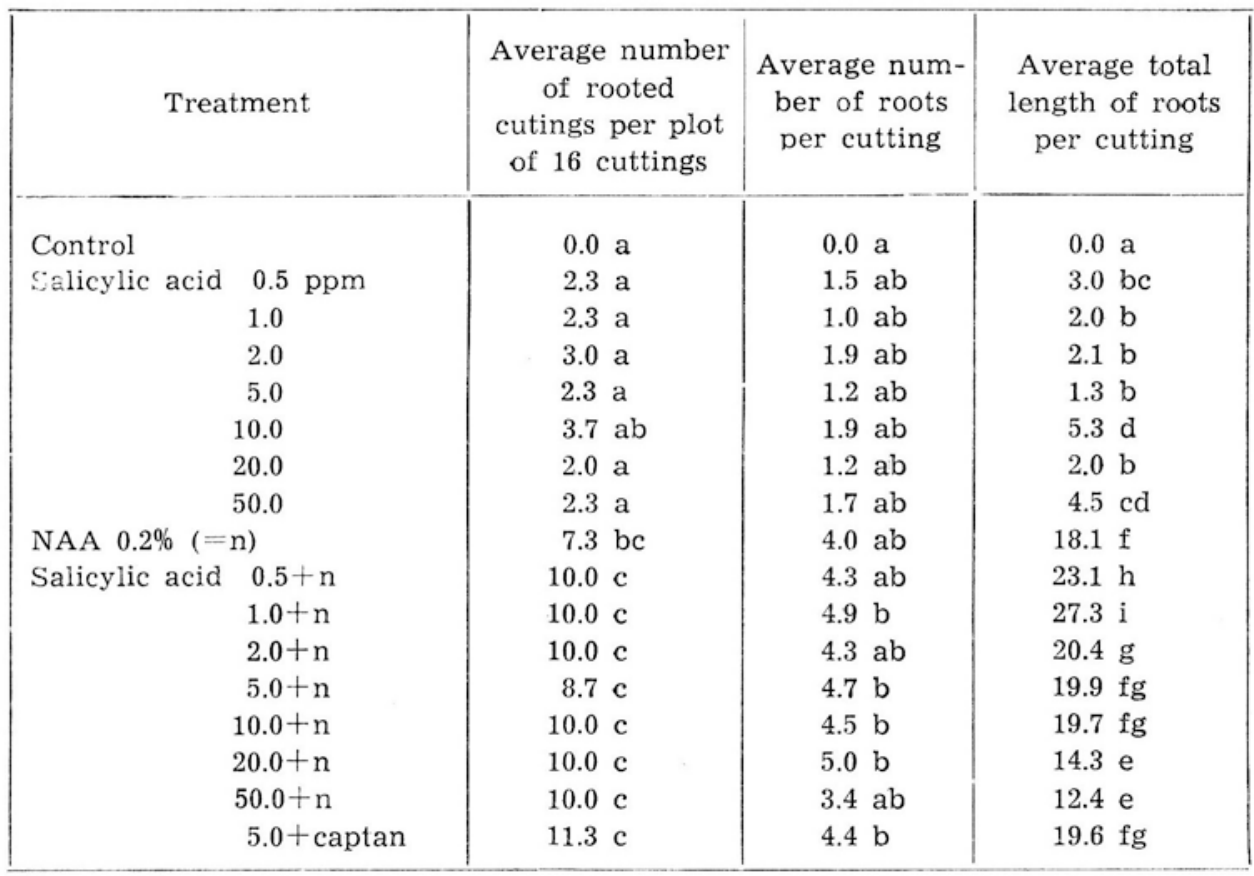

A separate experiment was set up to investigate if the date of taking cuttings influences their response to growth regulators. The results presented in Table 6 show that the numbers of rooted cuttings were the highest at the first date irrespective of the treatment. The combined treatment with an auxin and phenolic substance evoked the best rooting effect in all dates. The interaction "date" $\times$ "treatment" was insignificant in this case. This interaction was, however, significant for the traits "average number of roots per cutting" and "total length of roots per cutting". Presented results show that the mixture of auxin and phenolic substance shows most marked effects on these traits in latest date of treatment, exceeding markedly the effects obtained with auxin alone. At the first two dates of treatment the auxin was alone as effective or even more effective, concerning root number per cutting and total root length, than the above mixture. 
$\mathrm{Table} 5$

The influence of salicylic acid, NAA, and the fungicide Captan in the quick dip method* on the rooting of $P$. alba 'Tryńcza 3' cuttings

(Planted on August 3, results checked on August 25)

\begin{tabular}{|l|c|c|c|}
\hline \multicolumn{1}{|c|}{ Treatment } & $\begin{array}{c}\text { Average number } \\
\text { of rooted } \\
\text { cuttings per plot } \\
\text { of } 16 \text { cuttings }\end{array}$ & $\begin{array}{c}\text { Average number } \\
\text { of roots per } \\
\text { cutting }\end{array}$ & $\begin{array}{r}\text { Average total } \\
\text { length of roots } \\
\text { per cutting }\end{array}$ \\
\hline Control & $3.3 \mathrm{a}$ & $1.5 \mathrm{a}$ & $8.3 \mathrm{a}$ \\
scalicylic acid & $8.7 \mathrm{bcd}$ & $6.6 \mathrm{bc}$ & $15.8 \mathrm{ab}$ \\
500 ppm & $9.7 \mathrm{bcde}$ & $5.5 \mathrm{~b}$ & $16.7 \mathrm{abc}$ \\
1000 & $8.7 \mathrm{bcd}$ & $3.1 \mathrm{~b}$ & $9.7 \mathrm{a}$ \\
1500 & $11.8 \mathrm{def}$ & $5.4 \mathrm{~b}$ & $15.0 \mathrm{ab}$ \\
$1500+$ captan $(=\mathrm{c})$ & $10.0 \mathrm{bcde}$ & $4.7 \mathrm{~b}$ & $32.8 \mathrm{~cd}$ \\
5000 & $7.0 \mathrm{~b}$ & $11.7 \mathrm{~d}$ & $27.7 \mathrm{bc}$ \\
NAA 0.2\% $(=\mathrm{n})$ & $7.7 \mathrm{bc}$ & $10.7 \mathrm{~cd}$ & $43.7 \mathrm{~d}$ \\
$\mathrm{n}+\mathrm{c}$ & $11.3 \mathrm{def}$ & $18.3 \mathrm{e}$ & $68.0 \mathrm{e}$ \\
salicylic acid & $10.7 \mathrm{cdef}$ & $17.5 \mathrm{e}$ & $66.8 \mathrm{e}$ \\
$500+\mathrm{n}$ & $12.3 \mathrm{ef}$ & $17.5 \mathrm{e}$ & $67.5 \mathrm{e}$ \\
$1000+\mathrm{n}$ & $13.3 \mathrm{f}$ & $19.7 \mathrm{e}$ & $63.8 \mathrm{e}$ \\
$1500+\mathrm{n}$ & $11.0 \mathrm{cdef}$ & $17.1 \mathrm{e}$ & \\
$1500+\mathrm{n}+\mathrm{c}$ & & & \\
$5000+\mathrm{n}$ & & &
\end{tabular}

* The cuttings were dipped for 5 seconds in $50 \%$ ethanolic solution of salicylic acid. Other details as in Table 1.

\section{DISCUSSION}

There are very scanty data on the use of phenolic substances to promote adventitious root formation in cuttings of woody plants ( $\mathrm{L}$ e e and Tuckey 1971; Piątkowski et al. 1973; Jankiewicz et al. 1973). The authors have not found as yet any data concerning their use for poplars. Our results, these and unpublished, show that phenolic substances improve rooting of several clones of Populus alba and P. canescens, particularly when given together with auxin.

Phenolic substances: salicylic acid and pyrogallol applied by diluted solutions method promoted most root production in very low concentrations $0.5-20 \mathrm{mg} / \mathrm{l}$. In B a s u et al. (1969) experiments with Eranthemum cuttings salicylic acid given with auxin was also most effective in low concentrations 1-100 mg/l. Another phenolic substance-rutin showed marked root-promotive activity in as low concentration as $10^{-7} \mathrm{M}$ (Le e and Tuckey 1971). Pyrogallol was used in rather too high concentrations: $100 \mathrm{mg} / 1$ or more, by $\mathrm{Basu}$ (1972) and $\mathrm{Piątkowski}$ et al. (1973) with no sucess in root promotion. Lee and Tuckey (1971) 
Table 6

The effect of treatment and date of experiment on the rooting of cv. P. alba 'Tryńcza 3' cuttings

(Averages joined by the same letter are not significantly different) Other details as in Table 1

\begin{tabular}{|c|c|c|c|c|}
\hline \multirow{2}{*}{ Treatment } & \multicolumn{4}{|c|}{ Average number of rooted per plot of 8 cuttings } \\
\hline & $7-28 \mathrm{VI}$ & 7-28 VII & $5-26$ VIII & Mean \\
\hline Control & 6.7 & 2.3 & 2.3 & $3.4 \mathrm{a}$ \\
\hline NAA $0.2 \%(=n)$ & 7.3 & 5.3 & 4.0 & $5.5 \mathrm{~b}$ \\
\hline NAA $0.4 \%$ & 6.7 & 3.3 & 4.7 & $4.9 \mathrm{~b}$ \\
\hline Salicylic acid $1.0 \mathrm{ppm}+\mathrm{n}$ & 8.0 & 6.0 & 6.8 & $6.9 \mathrm{c}$ \\
\hline Mean & $7.2 \mathrm{~b}$ & $4.2 \mathrm{a}$ & $4.4 \mathrm{a}$ & \\
\hline Treatment & \multicolumn{4}{|c|}{ Average number of roots per cutting } \\
\hline Control & $7.2 \mathrm{~b}$ & $2.0 \mathrm{a}$ & $2.3 \mathrm{a}$ & \\
\hline NAA $0.2 \%$ & $26.0 \mathrm{f}$ & $21.0 \mathrm{def}$ & $11.4 \mathrm{bc}$ & \\
\hline NAA $0.4 \%$ & 22.3 def & $18.5 \mathrm{de}$ & $16.7 \mathrm{~cd}$ & \\
\hline Salicylic acid $1.0 \mathrm{ppm}+\mathrm{n}$ & $18.5 \mathrm{de}$ & $22.0 \mathrm{def}$ & 24.3 ef & \\
\hline Treatment & \multicolumn{4}{|c|}{ Average total length of roots per cutting } \\
\hline Control & $13.7 \mathrm{ab}$ & $7.5 \mathrm{a}$ & $15.2 \mathrm{ab}$ & \\
\hline NAA $0.2 \%$, & $84.1 \mathrm{de}$ & $80.2 \mathrm{de}$ & $42.0 \mathrm{c}$ & \\
\hline NAA $0.4 \%$ & 75.8 de & $80.3 \mathrm{de}$ & $32.7 \mathrm{bc}$ & \\
\hline Salicylic acid $1.0 \mathrm{ppm}+\mathrm{n}$ & $68.7 \mathrm{~d}$ & $91.5 \mathrm{e}$ & $94.1 \mathrm{e}$ & \\
\hline
\end{tabular}

have shown for rutin that too high concentrations of phenolic substance do not stimulate rooting.

Salicylic acid applied by quick-dip method (followed by auxin treatment) was most effective in concentrations $1000-5000 \mathrm{mg} / \mathrm{l}$. In the experiments of Lee and Tuckey (1971) and of $\mathrm{Jankiewicz}$ et al. (1973) the other phenolic substanes rutin and pyrogallol were effective in quick-dip method in similar concentrations.

The monophenol salicylic acid and a polyphenol pyrogallol showed similar root promoting activity, when combined with an auxin. Also in B a s u $(1969,1970)$ experiments a number of monophenols and polyphenols showed root-promotion of Phaseolus and Eranthemum cuttings. This does not support the suggestion that polyphenols increase synergistically the auxin effect on rooting by inhibiting IAA-oxidase system. B a s u (1971a) have found no direct relation between the activity of a given 
phenolic substance in rooting tests and its ability to stimulate or inhibit IAA-oxidase system. There was found (B a s u 1972), however, a correlation between the ability of some phenolic substances to stimulate the acropetal translocation of an auxin and their property to antagonize auxin-induced root promotion.

When salicylic acid was applied with auxin on different dates, their joint effect concerning root number per cutting and root length was most prominent in plant material taken on August 5. Although the effect on the number of rooted cuttings per plot was significant on all dates. Le e and Tuckey (1971) have shown that the synergism between the phenolic substance and auxin could be easily detected only in mature cuttings but not in immature ones.

The result of the presented paper may have practical meaning in poplar propagation. A combined treatment with a phenolic substance and auxin may markedly increase the number of rooted cuttings per frame, may prolongate the time of rooting the cuttings and may shorten the period needed to root them. This enables the nurseryman to have more rotations of cuttings per frame in a single season which is an important economic factor in vegetative propagation of poplars.

\section{REFERENCES}

B a s u R. N., 1969. Effect of auxin synergists in rooting of french bean (Phaseolus vulgaris L.) cuttings. Curr. Sci. 38: 533-535.

B a s u R. N., 1970. Indole acetic acid oxidizing system in relation to synergism and antagonism between auxin and non-auxinic chemicals in rooting of cuttings. Indian Jour. Plant Physiol. 13: 249-262.

B a s u R. N., 1971a: Transport of indoleacetic acid in bean cuttings in relation to root formation. Curr. Sci. 40: 427-429.

B a s u R. N., 1971b. Hormonal basis of regeneration of roots on cuttings. Indian Agric. 15: 69-85.

B a s u R. N., 1972. Effect of non-auxin chemicals on translocation of auxins in cuttings of Phaseolus vulgaris (L.). Jour. Expt. Botany 23: 357-365.

B a s u R. N., B ose T. K., and Roy B. N., Mukhopadhyay A., 1969. Auxin synergists in rooting of cuttings. Physiol. Plant. 22: 649-652.

Hackett W. P., 1970. The influence of auxin, catechol and methanolic tissue extracts in root initiation of aseptically cultured shoot apices of the juvenile and adult forms of Hedera helix, Jour. Amer. Soc. Hort. Sci. 95: 398-402.

Hess C. E., 1962. Characterization of rooting cofactors extracted from Hedera helix L. and Hibiscus rosa-sinensis L. Rep. 16-th Intern. Hort. Congress Brussels IV: 382-386.

Jankiewicz L. S., Bojarczuk T., and Piątkowski M. G., 1973. The effect of rutin and pyrogallol upon rooting of softwood cuttings of magnolias and of Syringa meyeri Schneid. Acta agrobot. 26: 277-283.

L e e C. I., and Tukey H. B., Jr, 1971. Induction of root-promoting substances in Evonymus alatus "Compactus" by intermittant mist. Jour. Amer. Soc. Hort. Sci. 96: 731-736. 
Piątkowski M. G., Jankiewicz L. S. and Kasprzyk S., 1973. Use of auxin, fungicides and rooting cofactors to induce adventitious root formation in softwood cuttings of apple, gooseberry and some ornamental plants. Acta agrobot. 26: 191-201.

Tomaszewski M., 1964. Mechanism of synergistic effects between auxin and some natural phenolic substances. [In:] Regulateurs Naturelles de la Croissance Végétale, CNRS, Gif-sur-Yvette.

Wplyw substancji fenolowych nạ zakorzenianie się sadzonek zielnych topoli Populus alba L. i P. canescens Sm.

\section{Streszczenie}

Potraktowanie sadzonek kwasem salicylowym lub pirogallolem, w połączeniu z traktowaniem auksyną - NAA zwiększało znacznie liczbę zakorzenionych sadzonek, liczbę korzeni na sadzonkę i sumę długości korzeni na sadzonkę ponad wartości otrzymane przy traktowaniu samą auksyną lub samą substancją fenolową. Synergizm między auksyną a związkami fenolowymi występował, jeśli chodzi o liczbę zakorzenionych sadzonek na poletko, przez caly sezon wegetacyjny, a jeśli chodzi o liczbę korzeni na sadzonkę i sumę długości korzeni na sadzonkę, przede wszystkim w drugiej połowie lata. Optymalnymi stężeniami związków fenolowych w metodzie roztworów rozcieńczonych były $0,5-20 \mathrm{mg} / 1$, a w metodzie roztworów stężonych $1000-5000 \mathrm{mg} / 1$. 